\title{
Constraints in Execution of Public Private Partnership Model in Dairy Farming
}

\author{
Khusboo Raj*, K. Ponnusamy, C.N. Kishore and Mehrunnissa Begum \\ Dairy Extension Division, ICAR-National Dairy Research Institute, \\ Karnal-132001, Haryana, India \\ *Corresponding author
}

\begin{abstract}
A B S T R A C T

\begin{tabular}{|c|c|}
\hline Keywords & $\begin{array}{l}\text { The present study was undertaken in Kaithal, Hisar and Mahendragarh districts of Haryana } \\
\text { state representing three different agro-climatic zones as classified by Haryana Kisan Ayog }\end{array}$ \\
\hline Cons & (HKA). Ten veterinary officers of animal husbandry department and 15 private field \\
\hline & functionaries from each district along with five clients from each Integrated Livestock \\
\hline $\begin{array}{l}\text { Functionaries, } \\
\text { Public Private }\end{array}$ & $\begin{array}{l}\text { Development Centers (ILDCs) maintained by J.K.Trust were selected randomly, } \\
\text { constituting a sample size of } 225 \text { for the study. Ex post facto research design was used for }\end{array}$ \\
\hline $\begin{array}{l}\text { Partnership, Gram } \\
\text { Vikash Yojna, } \\
\text { Gopal }\end{array}$ & $\begin{array}{l}\text { study. Primary data was collected using personal interview method. Most significant } \\
\text { establishment constraints perceived by public extension players in implementing PPP was }\end{array}$ \\
\hline Article Info & ds and recognition of \\
\hline $\begin{array}{l}\text { Accepted: } \\
10 \text { February } 2019 \\
\text { Available Online: } \\
10 \text { March } 2019\end{array}$ & $\begin{array}{l}\text { monthly income (mean score } 2.20 \text { ) and poor opportunity for training and development of } \\
\text { skills (mean score } 2.13 \text { ). Therefore, these constraints should be sorted out by those execute } \\
\text { the PPP model at state level in order to increase the efficiency of PPP outputs. }\end{array}$ \\
\hline
\end{tabular}
\end{abstract}

\section{Introduction}

The partnership approach apart from developing certain technologies also empowers farmers in terms of enhanced access to technology and market in India through organized farmers groups. The PPP approach supplements scarce resource, creates a more competitive environment and helps to improve efficiencies and reduce costs (Ponnusamy, 2013). PPP can act as an effective platform to bring together a pool of innovative talent with complimentary skill to foster a mutual learning and the development of creative ideas and propel the agriculture sector in the path of sustainable development. The public-private partnerships offer incredible scope to small farmers for realizing the potential market prices and thereby better livelihood (Ponnusamy et al., 2017). The resource-poor farmers often experience low returns due to interplay of both bio-physical and socio- economic factors. The existing market opportunities do not guarantee a 
reliable and steady income to the poor farmers. The PPP helps in addressing the constraints of farmers through offering a fair price for commodities, risk sharing, capacity building and timely payment (Hisrich and Peters, 2002; Krishna and Qaim, 2007; Reddy and Rao, 2011; Ponnusamy, 2013). Operational factors of the PPP linkage tend to differ from field to field based on the capability of partners, budget and time frame. Through PPP approach, impossibilities are made possible with the contribution of both public and private partners resulting in better economic conditions and livelihood of target population (Ponnusamy, 2013).

In this study, the constraints were operationalised as certain irresistible forces which have been impeding the execution of intended components of PPP project in dairying by farmers, JK Trust field functionaries and animal husbandry department officials. So it is necessary to understand the factors which are acting as constraints in execution of PPP model in dairy farming which will serve then as lessons for successful implementation of many other PPP models. Hence by keeping all these in mind, present study was undertaken to assess the constraints in execution of PPP model in dairy farming.

\section{Materials and Methods}

The present study was undertaken in Kaithal, Hissar and Mahendragarh districts which represent three different "Agro-climatic zones" of Haryana, where PPP model is operating and providing service in the field of dairying during 2017-18 for studying the constraints of private extension functionaries (Gopal) employed by J.K.Trust Gram Vikash Yojna which is running under Public Private Partnership Model (PPP) along with perceived constraints of public extension functionaries (Animal husbandry department). Primary data were collected by personal interview method.
The ex-post facto research design was followed for the study with 225 respondents, comprising 30 respondents from public extension functionaries, 45 respondents from private extension functionaries and 150 beneficiaries who were selected through simple random sampling. Before development of the schedule on constraints, an inventory of constraints was prepared by conducting preliminary survey in non-sample villages. It was supplemented with the discussions with few extension officers and researchers and by reviewing the available literature. Based on their views on importance and severity of each constraint, respondents were requested to indicate the constraint as: Highly Severe (HS), Moderately Severe (MS) and Least Severe (LS). After the data collection, the frequencies of HS, MS and LS were found which were again multiplied by 3,2 and 1 respectively. Their totals were added and later divided by total number of respondents for ranking in order to identify the severity of the constraint among three types of respondents.

\section{Results and Discussion}

\section{Constraints perceived by veterinary professionals}

Most significant establishment constraint perceived by public extension players are availing of credit from institutional sources for dairy farming (Mean score 3.00) followed by accessibility to remunerative market (2.83) for selling the surplus milk, difficulty in accessing subsidies (2.40), proper technical advice (1.90), getting support of family (1.06) and cooperation of friends and relatives for introducing innovations in dairy farming (Table 1). PPP will be effective only if sufficient resources are available with both public and private entities as transport facility for both the players are very important to perform field activities. Since, private players are more interested in profit maximization; 
quality of extension service is often compromised due to the urge to earn more at any cost.

Major constraints perceived by public extension agents in operation of PPP (Table 2) is related to access to the market (Mean score 2.46) followed by input availability (1.76), labour availability (1.16), timely payment (1.20), customer acceptance (1.10) and transparency in system (1.00). The probable reason for perceiving market access as major constraint in view of perishability of dairy products in nature and their flow in the market is very limited. When extension services are available and the required inputs are not available, it is very difficult to realize the intended benefits (Ponnusamy, 2006).

\section{Constraints perceived by Gopal}

The significant infrastructural constraints perceived by Gopal is timely availability of vaccine and medicine (Mean score 2.86) which got ranked as first, difficulty in timely reaching the spot and clients (2.11) as second rank, inadequate vehicle facility to reach (1.88) as third rank, inadequate AI equipment (1.20) as fourth rank and inadequate or poor quality items were perceived as least constraint (Table 3). Since Gopal face the difficulty of getting vaccines and medicine, they get dissatisfied. AI service is time bound, the difficulty in reaching client site often bring bad name to them from clients. If quality inputs are arranged by Gopal, they can get good recognition from clients. Above result is in agreement with Sasidhar (2001) who reported inadequate supply of medicine by the department, lack of knowledge and skills of advance surgical techniques and treatment as the main constraints among the public extension players. The most important personal recognition constraint faced by Gopal is lack of rewards and recognition of good works done by them (Mean score 3.00) because they were not given any kind of bonus or promotion for doing outstanding work. They also perceived poor status in society for working as Gopal. These mental blocks should be broken among the farming community and motivate the Gopal for good work (Table 4). This result is in agreement with (Ratnayke, 2012) who found that lack of awards and rewards were observed as serious constraints of veterinary extension professionals.

The significant constraints perceived by Gopal in career growth is poor opportunity for training and development of skills (Mean score 2.13) because once they get trained for doing AI, hardly they are getting opportunity for other skill oriented trainings. They also felt the inadequacy of interaction with other professionals (Mean score 1.82) and limited opportunity for progress in their profession (Table 5). Since it is a part time private job, career progression on the line of government set up is not possible. Above result is in agreement with Nagananda (2005) who found that lack of promotional opportunities and political interference in implementing the programme, lack of recognition of good workers were major constraints.

Table 6 depicts significant financial constraints perceived by Gopal such as inadequate monthly income (Mean score 2.20) because they were not earning enough by doing AI and for maintaining their better lifestyle they also had to opt for another job, followed by delayed payment of services (1.00). The opportunity should be created for income augmentation for Gopal such as input supply and marketing of agriculture products.

\section{Constraints perceived by beneficiary respondents}

The significant constraints perceived by beneficiary farmers are depicted in table 7 . The services provided by Gopal was perceived 
to be costly (Mean score 2.89). Farmers also reported poor conception rate in $\mathrm{AI}(1.88)$, AI not being done well on time (1.82), and lack of facility of Gopal during odd hours (1.20).
Farmers felt that some are untrained for performing AI services which may reduce the image of private extension professionals.

Table.1 Establishment constraints as expressed by public extension players

\begin{tabular}{|l|l|c|c|}
\hline Sr.No. & Particulars & Mean Score & Rank \\
\hline $\mathbf{1}$ & Credit availability & 3.00 & I \\
\hline $\mathbf{2}$ & Technical advice & 1.90 & IV \\
\hline $\mathbf{3}$ & Support of family & 1.06 & V \\
\hline $\mathbf{4}$ & Corporation of friends, relatives & 1.00 & VI \\
\hline $\mathbf{5}$ & Availability of market & 2.83 & II \\
\hline $\mathbf{6}$ & Subsidies/incentives & 2.40 & III \\
\hline
\end{tabular}

Table.2 Perceived operational constraints of public extension players

\begin{tabular}{|l|l|c|c|}
\hline Sr.No. & Particulars & Mean score & Rank \\
\hline $\mathbf{1}$ & Labour availability & 1.16 & III \\
\hline $\mathbf{2}$ & Input availability & 1.76 & II \\
\hline $\mathbf{3}$ & Market access & 2.46 & I \\
\hline $\mathbf{4}$ & Customer acceptance & 1.10 & V \\
\hline $\mathbf{5}$ & Timely payment & 1.20 & IV \\
\hline $\mathbf{6}$ & Transparency in system & 1.00 & VI \\
\hline
\end{tabular}

Table.3 Infrastructure constraints as perceived by Gopal

\begin{tabular}{|c|l|c|c|}
\hline S. No. & Particulars & Mean score & Rank \\
\hline $\mathbf{1 .}$ & Inadequate A.I Equipment & 1.20 & IV \\
\hline $\mathbf{2 .}$ & $\begin{array}{l}\text { Timely Availability of Vaccine And } \\
\text { Medicine }\end{array}$ & 2.86 & I \\
\hline $\mathbf{3 .}$ & Difficulty in timely reaching the client & 2.11 & II \\
\hline $\mathbf{4 .}$ & $\begin{array}{l}\text { Inadequate vehicle facility to reach the } \\
\text { client in time }\end{array}$ & 1.88 & III \\
\hline $\mathbf{5 .}$ & $\begin{array}{l}\text { Inadequate or poor quality input items } \\
\text { being made available }\end{array}$ & 1.00 & $\mathrm{~V}$ \\
\hline
\end{tabular}

Table.4 Personal recognition constraints as perceived by Gopal

\begin{tabular}{|c|l|c|c|}
\hline S. No. & Particulars & Mean score & Rank \\
\hline $\mathbf{1}$ & $\begin{array}{l}\text { Lack of rewards and recognition of good } \\
\text { works }\end{array}$ & 3.00 & I \\
\hline $\mathbf{2}$ & Poor status in society & 1.77 & II \\
\hline
\end{tabular}


Table.5 Career growth constraints as perceived by Gopal

\begin{tabular}{|l|l|c|c|}
\hline S. No & Particulars & Mean score & Rank \\
\hline $\mathbf{1}$ & $\begin{array}{l}\text { Limited opportunity for progress in } \\
\text { chosen profession }\end{array}$ & 1.08 & III \\
\hline $\mathbf{2}$ & $\begin{array}{l}\text { Poor opportunity for training and } \\
\text { development of skill }\end{array}$ & 2.13 & I \\
\hline $\mathbf{3}$ & $\begin{array}{l}\text { Inadequacy or less opportunity of } \\
\text { interaction with other professionals }\end{array}$ & 1.82 & II \\
\hline
\end{tabular}

Table.6 Financial constraints as perceived by Gopal

\begin{tabular}{|l|l|c|c|}
\hline S. No. & Particulars & Mean score & Rank \\
\hline $\mathbf{1}$ & Inadequate monthly income & 2.20 & I \\
\hline $\mathbf{2}$ & Delayed payment of services & 1.00 & II \\
\hline
\end{tabular}

Table.7 Constraints perceived by beneficiary respondents

\begin{tabular}{|l|l|c|c|}
\hline S.No. & Particulars & Mean score & Rank \\
\hline $\mathbf{1 .}$ & Lack of facility for Gopal during odd hours & 1.20 & IV \\
\hline $\mathbf{2}$ & $\begin{array}{l}\text { Artificial insemination not being done well } \\
\text { on time }\end{array}$ & 1.82 & III \\
\hline $\mathbf{3}$ & Poor conception rate in A.I & 1.88 & II \\
\hline $\mathbf{4}$ & Untrained gopal & 1.00 & V \\
\hline $\mathbf{5}$ & Services are costly & 2.89 & I \\
\hline
\end{tabular}

Proper monitoring by both animal husbandry department and J.K. Trust is very essential to check the overcharging of AI services by Gopals. The private extension players should be adequately trained on key areas of breeding and health management as poorly trained person would bring bad name to the schemes as well as organization. Ponnusamy and Walli (2007) while comparing dairy cooperatives and contract dairy farming highlighted the strength and weaknesses of both public and private place.

Adequate transport facility should be facilitated to enable Gopal to reach the site of clients even during odd hours. Periodical quarterly meeting should be conducted at block and district level to sort out the practical issues prevailing with Gopal and address the concerns of farmers.

In conclusion, PPP is emerging as an appropriate extension model in order to balance the roles and constraints which are currently being faced by both public and private extension players. Identification of major constraints in execution of PPP model in dairy farming would play key role in successful execution of PPP model. It helps in assessing the various factors either from public or private sector which is acting as a hurdle in smooth running and implementation of PPP. In any PPP model, both private as well as public sector play vital role which necessitates in studying constraints from both sides. The finding of present study revealed 
that most significant constraint for establishment of PPP as perceived by public functionaries was found to be lack of financial support and the operational constraint was remunerative market access to milk and milk products. On other hand, major constraints perceived by private functionaries were inadequate AI equipment, lack of reward and recognition of good works and poor opportunity for training and development of skills. This warrants the policy makers at state level to address the constraints in appropriate decision making bodies so that the real benefits of PPP can be harnessed by different stakeholders especially the farming community.

\section{Acknowledgement}

The authors are thankful to Director ICARNDRI, Karnal, J.K Trust, Department of Animal Husbandry, Haryana for providing necessary facilities. The authors are also thankful to all the farmers and field extension functionaries for their kind cooperation during research studies.

\section{References}

Hisrich, R. D. and Peters, M. P. (2002). Tata McGraw Hill Publishing Co.Ltd, New Delhi. Entrepreneurship, p 663.

Krishna, V.V. and Qaim, M. (2007). Estimating the adoption of Bt eggplant in India: Who benefits from public- private partnership? Food Policy, 32: 523-543.

Ponnusamy, K. (2006). Multidimensional analysis of integrated farming system in the coastal agro-eco system of Tamil Nadu. Ph.D. Thesis. NDRI (Deemed University), Karnal, Haryana.

Ponnusamy, K and Walli, T.K. (2007). Contract Dairy Farming Versus Dairy Cooperatives- Relative Strengths and Weaknesses. Indian Dairyman. 59 (4): 53-60

Ponnusamy, K. (2013). Impact of public private partnership in agriculture: A review. Indian Journal of Agricultural Sciences, 83(8): 803-8.

Ponnusamy, K., and Pachaiyappan, K. (2018). Strengthening extension research in animal husbandry: review of issues and strategies. Indian Journal of Animal Sciences, 88(2): 137-143.

Ponnusamy, K, Bonny, B. P. and Das, M. D. (2017). Impact of public private partnership model on women empowerment in agriculture. Indian Journal of Agricultural Sciences, 87(5): 613-617.

Reddy, G. P. and Rao, K. H. (2011). Public Private Partnership in Agriculture Challenges and Opportunities. Summary proceedings and recommendations of National Workshop. National Academy of Agricultural Research Management, Hyderabad.

\section{How to cite this article:}

Khusboo Raj, K. Ponnusamy, C.N. Kishore and Mehrunnissa Begum. 2019. Constraints in Execution of Public Private Partnership Model in Dairy Farming. Int.J.Curr.Microbiol.App.Sci. 8(03): 1185-1190. doi: https://doi.org/10.20546/ijcmas.2019.803.140 